\title{
高減衰オイルダンパーの実大性 A REAL SCALE PERFORMANCE TEST 能実験 OF A HIGH CAPACITY OIL DAMPER
}

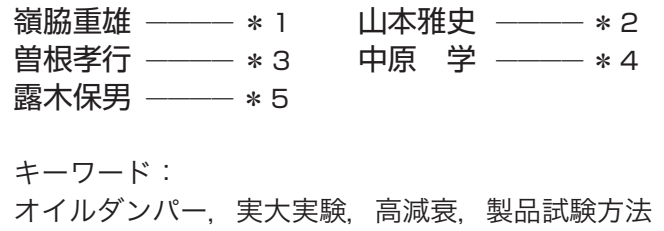

Keywords:

Oil damper, Real scale test, High capacity in damping, Product test method

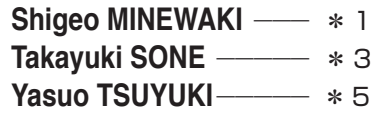

Masashi YAMAMOTO $-* 2$

Manabu NAKAHARA - $* 4$

The authors developed an oil damper with a new and novel configuration. That has the high damping capacity, $6000 \mathrm{kN}$ force in maximum. Through a real scale performance test with conditions of velocity of $450 \mathrm{~mm} / \mathrm{s}$ or of displacement amplitude of $184 \mathrm{~mm}$ both in maximum, it was confirmed the developed damper possesses the designed characteristics. In another test using earthquake responded waves, the device showed an expected performance, as well.

It was also found out that a new test method, employing the feature on the configuration consisted of three element dampers, and will make product testing possible, was precise enough.

\section{1.はじめに}

建物の耐震安全性向上のために制振用ダンパーを用いる事例は十 数年来増加の傾向を維持しており ${ }^{1)}$ 、高層建物では一般的な技術と言 える。中でも近年の、建物の巨大化、極大地震動に対する余裕度の 確保、ダンパー設置個所が限定されることを反映した集約化への要 望などを考慮すると、制振用ダンパーの高容量化が求められるのは 必然と言える。また、2011 年東北地方太平洋沖地震の際に東京都内 の高層建物で生じた継続時間の長い摇れやそれに伴って生じた什器 の移動・転倒、ドア開閉の障害など ${ }^{2}$ に対する対策の要請に応えるこ とを併せて考え、筆者らは、中小地震から有効な減衰効果を発揮す る特性をもつオイルダンパーの高容量化を開発対象とした。

本論では開発品の実大性能実験結果について報告する。

\section{2. 高減衰オイルダンパー}

筆者らが考案した高減衰オイルダンパーの構成概念図（断面）を 図 1 に示す。要素ダンパー3 基を材軸方向に積層し、共通のピストン ロッドで稼働させることで 3 倍の減衰力を得ることができる ${ }^{3)}$ 。最大 減衰力の目標值は $6000 \mathrm{kN}$ とした。この值は、合理的な構造部材サイ ズとの関連においてダンパー減衰力を定めるべきであることや、ダ ンパー製造、部品調達の容易さなどを勘案したものである。

\section{3. 実験計画}

\section{1 試験体}

上記概念に基づき設計した最大減衰力 $6000 \mathrm{kN}$ の高減衰オイルダ ンパーを対象とする。減衰特性はバイリニア型である。設計諸元を

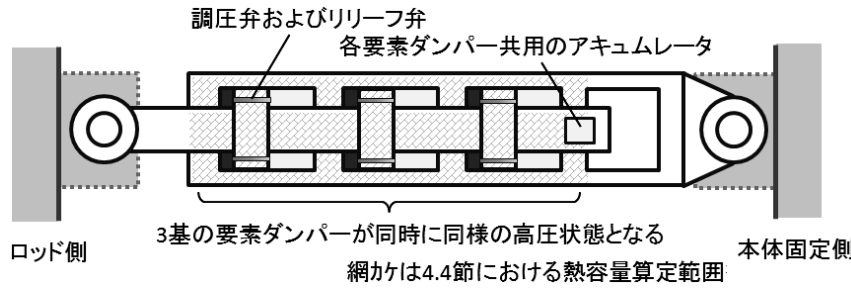

図 1 高減衰オイルダンパー構成概念図

表 1 試験体設計諸元

\begin{tabular}{|c|c|c|c|c|c|}
\hline 項目 & 単位 & 数値 & 項目 & 単位 & 数値 \\
\hline 全長 (中立時) & $\mathrm{mm}$ & 4250 & ストローク & $\mathrm{mm}$ & \pm 200 \\
\hline 本体最外径 & $\mathrm{mm}$ & 530 & ダンパー剛性 $K$ & $\mathrm{kN} / \mathrm{mm}$ & 900 \\
\hline 一次減衰係数 $\mathrm{C} 1$ & $\mathrm{kN} /(\mathrm{mm} / \mathrm{s})$ & 225 & ニ次減衰係数 C2 & $\mathrm{kN} /(\mathrm{mm} / \mathrm{s})$ & 2.80 \\
\hline リリーフ速度 $V r r$ & $\mathrm{~mm} / \mathrm{s}$ & 21.33 & リリーフ荷重 $F r$ & $\mathrm{kN}$ & 4800 \\
\hline 最大速度 $V l i m$ & $\mathrm{~mm} / \mathrm{s}$ & 450 & 最大減衰カ $F l i m$ & $\mathrm{kN}$ & 6000 \\
\hline
\end{tabular}

\section{表 2 試験機性能諸元（長軸方向）}

\begin{tabular}{|c|c|c|}
\hline 項目 & 単位 & 定格値 \\
\hline 最大荷重 & $\mathrm{kN}$ & 8900 \\
\hline 最大変位 & $\mathrm{mm}$ & \pm 1220 \\
\hline 最大速度 & $\mathrm{mm} / \mathrm{s}$ & \pm 1778 \\
\hline
\end{tabular}

表 1 に示す。ストロークは同一の基本設計で製作可能な最大值とし た。図 1 中に示すように 3 基共用のアキュムレータをピストンロッ ドに内蔵する。試験体姿図を図 2 中に示す。

\section{2 実験施設}

米国 University of California San Diego 校が所有する大規模動的加力 実験施設 ${ }^{4)}$ を用いた。加振方向は試験機の長軸方向である。表 2 に試 験機性能諸元を、写真 1 に取付状況を示す。主要計測点模式図を図 2

\footnotetext{
“1 (株竹中工務店技術研究所振動制御グループ 主任研究員・博士（工学） （干 270-1395 千葉県印西市大塚 1-5-1）

(株竹中工務店技術研究所地震工学部 部長・博士（工学)

3 (株竹中工務店技術研究所振動制御グループ 研究主任

'1 Chief Researcher, Structural Dynamics Group, Research \& Development Institute, Takenaka Corporation, Dr. Eng.

General Manager, Earthquake Engineering Department, Research \& Development Institute, Takenaka Corporation, Dr. Eng.

${ }^{*}$ Assoc. Chief Researcher, Structural Dynamics Group, Research \& Development Institute, Takenaka Corporation

4 Engineering Staff Manager, Production Headquarters, Kayaba System Machinery Executive Managing Director, Kayaba System Machinery 
に、一覧を表 3 に示す。変位はダンパー伸長方向を正とした。試験 体に発生する減衰力は各油室の圧力測定值より求めた。

\section{3 実験項目}

実験項目およびそれぞれの目的を以下に述べる。

1) 減衰性能確認実験：正弦波加振により所定の速度一減衰力関係が 実現されていることを確認する。

2) 部分バイパス実験 : 製作メーカーが保有する容量 $2000 \mathrm{kN}$ 程度の 試験機によって製品出荷試験を可能とするロジックを確認する。

3) ランダム波加振実験：建物の地震応答波形を模擬したランダム波 に対しても、所定の減衰性能が発現されることを確認する。

4) 多数回繰り返し実験 : 温度上昇が顕著に現れる状態まで加振を繰 り返し、ダンパーの熱容量と温度上昇量の関係を確認する。

\section{4 実験条件}

1) 減衰性能確認実験：本開発ダンパーの適用対象として考えられる 超高層建物の、i) 1 次振動数となり得る領域、ii) 速度応答が卓越す る可能性のある振動数領域、iii) 副次的な影響を与える可能性のある 振動数領域一を想定した 3 振動数水準において速度一減衰力関係を 確認する。それぞれを代表する水準として $0.2 \mathrm{~Hz} 、 1.0 \mathrm{~Hz} 、 1.6 \mathrm{~Hz}$ を与え

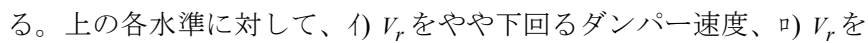
やや上回るダンパー速度、川) 最大速度付近一の 3 速度水準を設定す る。但し、振動数 $0.2 \mathrm{~Hz}$ かつ最大速度 $450 \mathrm{~mm} / \mathrm{s}$ の条件は変形過大と なるので、振動数 $0.39 \mathrm{~Hz}$ で代替する。ここでダンパー速度（以下 $v_{d}$ ) とはダンパー内部の作動油流速に直接かかわるピストンの有効速度 を意味する。実験条件を表 4 中○印で示す。なお、また、以下では、 $V_{r}$ を下回る速度領域を $\mathrm{C} 1$ 領域、上回る速度領域を $\mathrm{C} 2$ 領域と呼ぶ。

加振波形概念図を図 3 に示寸。所定振幅の正弦波 5 サイクルの前 後 1 サイクルにテーパーを掛けたものである。実験結果を整理する 際には原則として 3 サイクル目を対象とする。

2) 部分バイパス実験 : 試験体には要素ダンパー毎に両油室のストロ ークエンド付近を連結する実験用バイパス配管が設けられている。 今般実験における最大変位土 $184 \mathrm{~mm}$ が生じても同配管の流路は確保 される。同配管を順次開閉することで各要素ダンパーの有効／無効 を切り替えデータを取得する。実験ケース分類を表 5 に示す。要素 ダンパー番号は本体固定側を 1 、ロッド側を 3 とする (図 1 参照)。実 験ケース T は上述の減衰性能確認実験で実施するものである。

たとえば、実験ケース 1 による特性 $Z_{1}$ は、要素ダンパー 1 が有効 な時の特性 $z_{1}$ と要素ダンパー2,3 がバイパスされた時の特性 $z_{B 2}, z_{B 3}$ 、 および要素ダンパー部以外の摩擦等を表す残差項 $z_{e}$ の和として、

$$
Z_{1}=z_{1}+z_{B 2}+z_{B 3}+z_{e}
$$

と表現でき、他の実験ケース $T, 2,3,0$ もこれに倣って表現し整理する と、式(1)を導くことができる ${ }^{5)}$ 。 Z は実験による評価值であり、C1 領域においては $\mathrm{C} 1 、 \mathrm{C} 2$ 領域については発生減衰力 $F$ を用いる。

$$
\left.\begin{array}{l}
Z_{T}=Z_{\text {sum }} \\
Z_{\text {sum }}=Z_{1}+Z_{2}+Z_{3}-2 Z_{0}
\end{array}\right\}
$$

振動数とダンパー速度の組合せを表 4 中 印で示す。振動数水準 は、製品出荷試験の条件として設定されうる範囲を考慮して、減衰 性能確認実験で用いた水準のうち 2 水準を採った。加振波形は減衰 性能確認実験と同様である。

本実験により第一式が適切な精度で成立すれば、今後の出荷試験 を第二式のみで実施できるというロジックである。

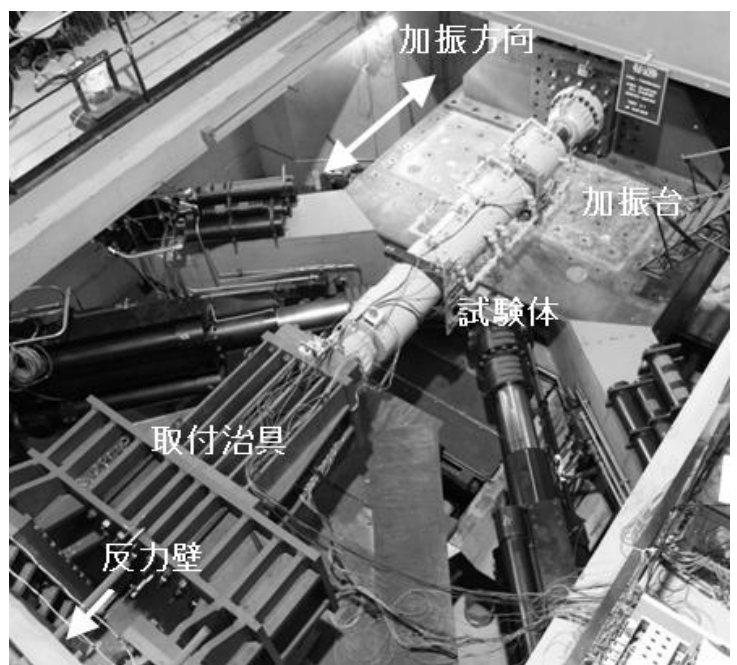

写真 1 試験体取付状況

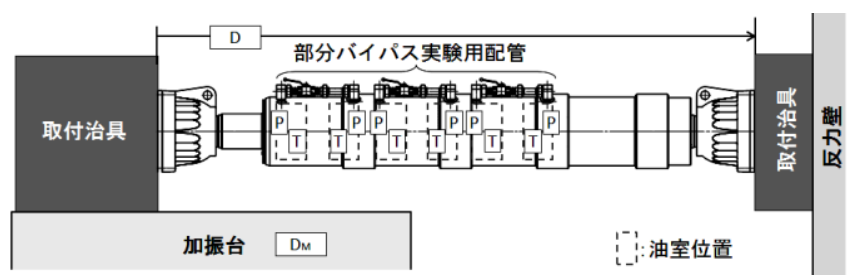

\begin{tabular}{|c|c|c|}
\hline 記号 & 計測内容 & 設置位置 \\
\hline $\mathrm{D}$ & ダンパー全体変形 & ダンパー全長間 \\
\hline $\mathrm{P}$ & 各油室圧力 & 各油室のストロークエンド近傍 \\
\hline $\mathrm{T}$ & 表面温度 & 各油室位置に相当する鋼材部表面 \\
\hline DM & 加振台変位フイードバック & 実験施設内蔵 \\
\hline
\end{tabular}

図 2 主要計測点模式図（図中記号は表 3 参照）

\begin{tabular}{|c|c|c|c|}
\hline \multirow{2}{*}{$\begin{array}{l}\text { ダンパー速度 } \\
\text { 目標值 }(\mathrm{mm} / \mathrm{s})\end{array}$} & \multicolumn{3}{|c|}{ 加振振動数 $(\mathrm{Hz})$} \\
\hline & 0.2 & 1.0 & 1.6 \\
\hline 16 & $\mathrm{O}$, & $\mathrm{O}$, & $\mathrm{O}$ \\
\hline 150 & $\mathrm{O}$, & $\mathrm{O}$, & 0 \\
\hline 450 & $(0.39 \mathrm{~Hz}) \mathrm{O}$ & $\mathrm{O}$, & $\mathrm{O}$ \\
\hline
\end{tabular}

表 4 減衰性能確認実験および部分バイパス実験 実験条件一覧

O：減衰性能確認実験, 部分バイパス実験

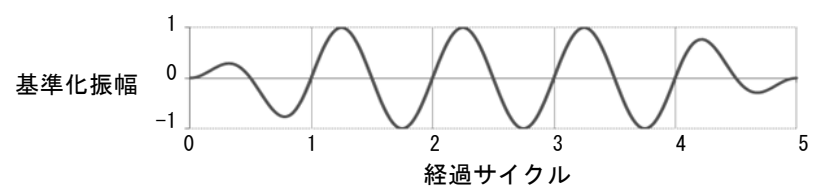

図 3 加振波形概念図(正弦波)

\begin{tabular}{|c|c|c|c|}
\hline 実験ケース & 要素ダンパー3 & 要素ダンパー2 & 要素ダンパー1 \\
\hline$T$ & 有効（配管閉） & 有効（配管閉） & 有効（配管閉） \\
\hline 1 & 無効（" 開） & 無効（" 開） & 有効（" 閉） \\
\hline 2 & 無効（" 開） & 有効（" 閉） & 無効（ \\
\hline 3 & 有効（" 閉） & 無効（ $"$ 開） & 無効（" 開） \\
\hline 0 & 無効（ & 無効（ $"$ 開） & 無効（" 開） \\
\hline
\end{tabular}

表 5 部分バイパス実験ケース分類

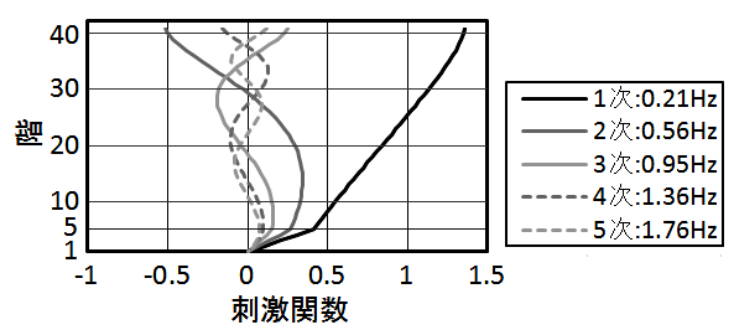

図 4 仮想建物モデルの刺激関数および固有振動数 
3) ランダム波加振実験 : 建物の地震応答波形を模擬する実験用入力 波形を、仮想の 40 階建超高層建物モデルの地震応答解析によって作 成した。同仮想モデルはダンパー試験体に生じるストローク変位お よび速度の双方が適度に大きくなることを考慮して諸元を設定した ものであり、建物としての成立性を十分に検討したものではない。1 $\sim 5$ 次の刺激関数と固有振動数を図 4 に示す。上部構造は弾性せん断 モデルとし、等価減衰定数の平均值が $5 \%$ 程度となるような層間ダン パーを配置した。高減衰オイルダンパーは 5 階床一地上間にシアリ ンク型の取付部材を介して設置した。地震動入力位置は 1 階床位置 とし、告示適合波八戸位相（極稀に発生するレベル）および同神戸 位相（極稀に発生するレベルの振幅を 1.2 倍したもの）一の 2 波を用 いた。前者による 5 階床位置相対変位を $\mathrm{KH}$ 波、後者を $\mathrm{KK} 1.2$ 波と 呼び、加振台変位信号として用いる。両波形を図 5 に示す。前者は 比較的大きな荷重振幅が長く繰り返されるケース、後者は最大荷重 に近い荷重が単発的に与えられるケースとして位置づけた。

4) 多数回繰り返し実験：1)で述べた減衰性能確認実験の 1 ケースで ある振動数 $0.39 \mathrm{~Hz}$ 、最大速度 $450 \mathrm{~mm} / \mathrm{s}$ の加振（1 回目と称す）を実施 したのち、振動数 $0.39 \mathrm{~Hz}$ 、最大速度 $380 \mathrm{~mm} / \mathrm{s}$ の加振を繰り返す（2 回 目、3 回目...と称寸)。加振波形は図 3 に示したものとする。加振間 には油温の上昇が筐体 (鋼材) 表面まで伝達される時間として、15 30 分のインターバルを設ける。後続の加振で製品の限界温度として設 定されている $80^{\circ} \mathrm{C}$ を超えると予測された場合には実験を終了寸る。

\section{4. 実験結果}

\section{1 減衰性能確認実験}

実験結果として得られた減衰性能曲線を図 6 に示寸。結果の整理 に当たっては、全体変形からダンパー剛性 $K$ による変形分を差引き、 さらに微分してダンパー速度 $v_{d}$ の時刻歴を求めた上で、 $\mathrm{C} 1$ 領域につ いては、減衰力 $F$ の正負最大值近傍（原則として 0.8 倍以上）のデー 夕を用いて線形近似により $\mathrm{C} 1$ を $F-v_{d}$ 関係の勾配として求めた。図 6 上には $F$ の最大值 (正負問わず) に対応する点としてプロットした。 $\mathrm{C} 2$ 領域については、正負それぞれについて $F$ の最大值と同発生時刻 の $v_{d}$ の関係を求めた。0.2Hz、0.39Hz の実験ケースについては $5 \mathrm{~Hz}$ の、1.0Hz、1.6Hzについては $10 \mathrm{~Hz}$ のローパスフィルターを施した。

製品製造上の標準值および許容範囲 $( \pm 10 \%)$ を図中に実線および 破線で示す。振動数水準によらず、いずれの実験結果も精度よく標 準值近傍の值を示す。破線丸中に示したメーカー保有試駼機による、 より小振幅 $\left(v_{d}\right.$ 目標值 $\left.8 \mathrm{~mm} / \mathrm{s}\right)$ の実験結果も概放同様であった。

\section{2 部分バイパス実験}

実験結果を表 6 に示す。 $\mathrm{C} 1$ 領域の実験については 4.1 と同様に C1 を求めた。C2 領域については、実験条件の $v_{d}$ 目標值近傍で実験ケー ス $T, 1,2,3,0$ に共通な速度を定め、正（引）側、負（押）側それぞれ について対応する $F$ を取得した。実験データにはサイクルごとに若 干のばらつきがあることを考慮して、2 4 サイクル目の増速時および 減速時の計 6 データを取得した上で平均を採った。実験ケース $1,2,3,0$ の結果から式(1) 第二式により $Z_{\text {sum }}$ を求めた。

部分バイパス実験を製品出荷試験に用いることを想定した場合、 ダンパーの製造工程を総合的に考慮すると式(1)の誤差を $\pm 3 \%$ 以内 とすることが望まれる。表中の $Z_{\text {sum }} / Z_{T}$ を誤差に読み替えると最大は 1.7\%であり、同試験ロジックの成立性を示寸結果といえる。

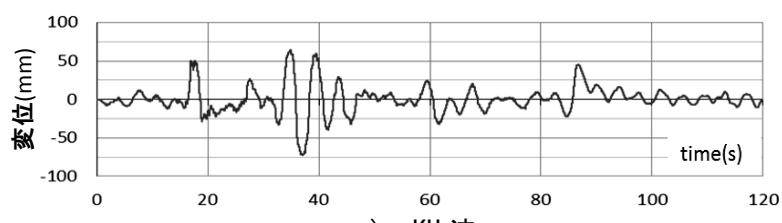

a) $\mathrm{KH}$ 波

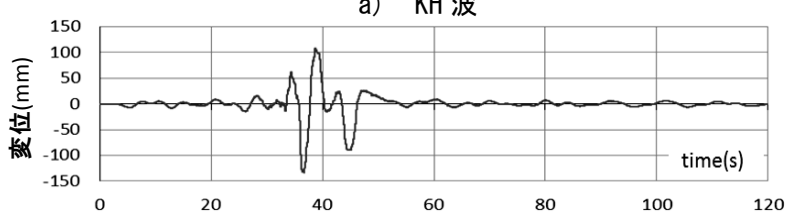

b) KK1. 2 波

図 5 ランダム波加振実験入力変位波形

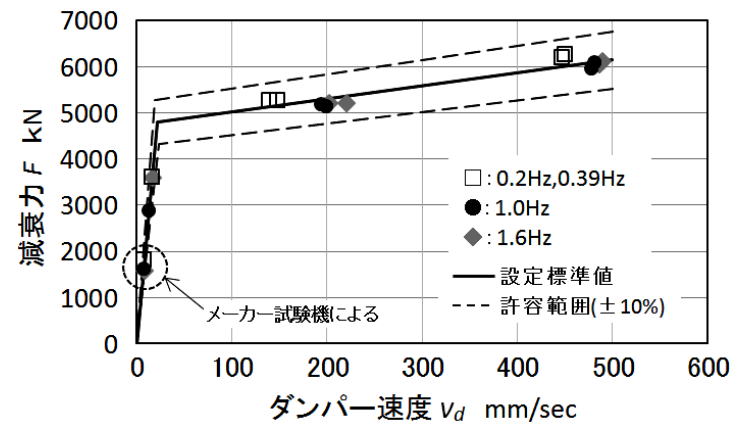

図 6 減衰性能確認実験結果

表 6 部分バイパス実験結果

\begin{tabular}{|c|c|c|c|c|c|c|}
\hline \multicolumn{2}{|c|}{ 実験条件 } & \multirow{2}{*}{ 正/負 } & \multirow{2}{*}{$Z_{\text {sum }}$} & \multirow{2}{*}{$Z_{T}$} & \multirow{2}{*}{$\frac{Z_{\text {sum }}}{Z_{T}}$} & \multirow{2}{*}{ 評価値 $Z$} \\
\hline 加振振動数 $(\mathrm{Hz})$ & $v_{d}$ 目標値 $(\mathrm{mm} / \mathrm{s})$ & & & & & \\
\hline \multirow{3}{*}{0.2} & 16 & - & 214.3 & 218.1 & 0.983 & $\mathrm{C} 1(\mathrm{kN} \cdot \mathrm{s} / \mathrm{mm})$ \\
\hline & \multirow[t]{2}{*}{150} & 正 & 5180 & 5135 & 1.009 & \multirow{4}{*}{$F(\mathrm{kN})$} \\
\hline & & 負 & -5192 & -5165 & 1.005 & \\
\hline \multirow[t]{2}{*}{0.39} & \multirow[t]{2}{*}{450} & 正 & 6187 & 6244 & 0.991 & \\
\hline & & 負 & -6099 & -6157 & 0.991 & \\
\hline \multirow[t]{5}{*}{1.0} & 16 & - & 212.3 & 211.4 & 1.004 & $\mathrm{C} 1$ \\
\hline & \multirow[t]{2}{*}{150} & 正 & 5106 & 5076 & 1.006 & \multirow[t]{4}{*}{$F$} \\
\hline & & 負 & -5083 & -5020 & 1.013 & \\
\hline & \multirow[t]{2}{*}{450} & 正 & 5969 & 5960 & 1.002 & \\
\hline & & 負 & -5934 & -5873 & 1.010 & \\
\hline
\end{tabular}
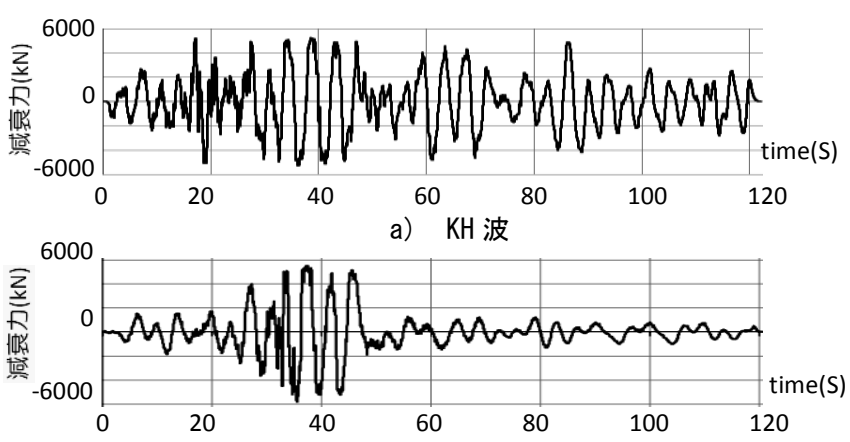

b) KK1. 2 波

図 7 ランダム波加振実験減衰力時刻歴

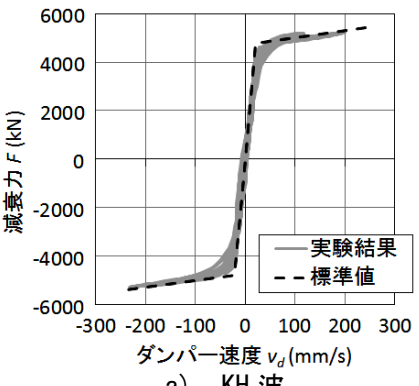

a) $\mathrm{KH}$ 波

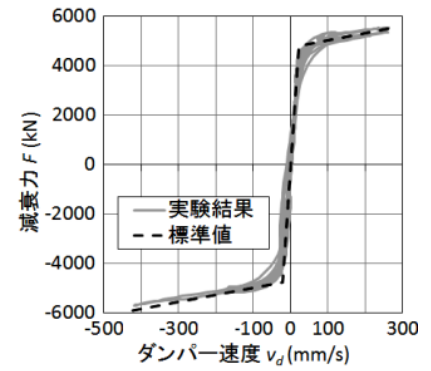

b) KK1. 2 波
図 8 ランダム波加振実験ダンパー速度一減衰力関係 
また、低速度水準における実験ケース 0 により把握できるダンパ 一全体の摩擦力は $10 \mathrm{kN}$ 程度であった。これは、中小地震時において 高減衰オイルダンパーに期待される減衰力に比べごく小さい。

\section{3 ランダム波加振実験}

図 7 に、実験結果として得られた減衰力時刻歴波形を示す。前述 した両波形の位置づけが概水実現されている。

図 8 に両実験のダンパー速度一減衰力関係を減衰特性図上に示寸。 ダンパー速度は加振台変位記録を用いて求めたので、剛性寄与分と して取付治具等実験施設の変形も考慮した。取付治具等の剛性值は 今般の一連の実験に伴う測定に基づき $1,400 \mathrm{kN} / \mathrm{mm}$ を用いた。いずれ の実験においても時々刻々のダンパー速度一減衰力関係は試験体ダ ンパーの減衰性能設計標準值に近似した軌跡を描く。

図 9 に両実験の加振台変位一減衰力関係を、ばねーダッシュポッ 卜を単純に直列させた Maxwell モデルによる解析結果と重ね書きし て示す。Maxwell モデルには表 7 の諸元を用いた。実験結果と解析結 果は良好に一致し、高減衰オイルダンパーの特性は単純な Maxwell モデルで表現できることがわかる。

\section{4 多数回繰り返し実験}

図 10 に温度計測点 6 点の最高值及び平均值の時間变化を示す。 5 回目終了後に計測温度最高值は限界温度に近接した $73.8^{\circ} \mathrm{C}$ に至った。 表 8 には各加振における吸収エネルギーを示す。比較のためランダ ム波加振実験における吸収エネルギーも併せて示す。

図 10 中の計算值は、各加振における吸収エネルギーを要素ダンパ 一近傍（図 1 中網カケで示した、筐体、シリンダ、ロッド、要素ダ ンパー隔壁等の鋼材全部および要素ダンパー油部）の熱容量 $1390 \mathrm{~kJ}$ ${ }^{\circ} \mathrm{C}$ で除して累加したものである。4,5 回目の計測温度最高值と計算 值はほぼ一致しており、限界温度に達するかどうかの判定は上記の ような簡単な仮定により可能と考えられる。また、加振条件が同一 である 2 回目から 5 回目までの吸収エネルギーはほぼ同一であり、 図示しないが、その間の減衰力ーダンパー变位関係もほぼ十全に一 致することから、この程度の繰り返し条件においては、高減衰オイ ルダンパーの力学特性に変化は見られないと言える。

図 10 中には、比較のため $2000 \mathrm{kN}$ オイルダンパー3 基の熱容量に 基づく計算值を一点鎖線で示した。2000kN $\times 3$ 基では限界温度 $80^{\circ} \mathrm{C}$ に未達なのは 2 回目までであり、高減衰オイルダンパーの温度上昇 に対する余裕度は相対的に大きい。これは、筐体の強度設計におい て鋼材体積を相対的に増大させたことが有利に働いたものである。

\section{5. まとめ}

高減衰オイルダンパーの実大性能実験結果は以下のようにまとめ られる。

・正弦波加振による減衰性能確認実験において、所定の減衰性能が 精度よく確認された。また、建物の地震応答波形を模擬したランダ ム波に対しても、所定の速度一減衰力関係が時々刻々発揮されてい ることが確認された。

・多数回繰り返し実験では、限界温度の設定值を超えない温度領域 において力学特性に変化が見られないことを確認した。また、限界 温度への到達判定は油室近傍の熱容量を用いた検討で可能であるこ とを示し、既往製品に比して余裕度が大きいことも明らかにした。 ・部分バイパス実験によるダンパー全体特性評価結果は、ダンパー

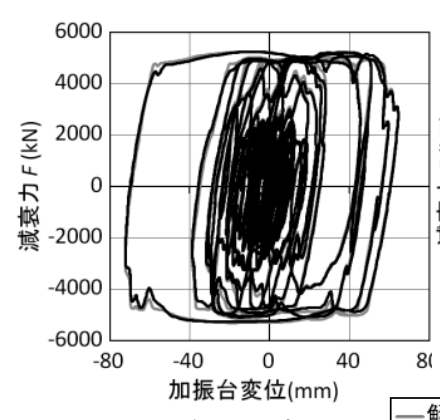

a) $\mathrm{KH}$ 波

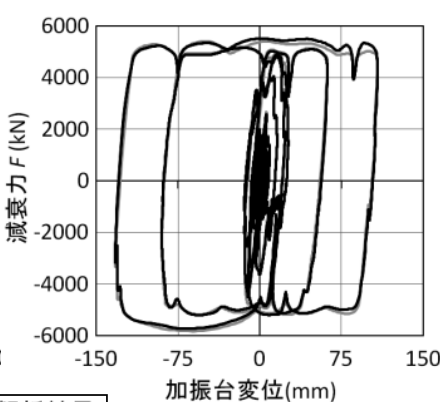

b) KK1. 2 波
図 9 ランダム波加振実験加振台変位一減衰力関係

表 7 Maxwell モデル諸元

\begin{tabular}{|c|c|c|c|}
\hline 項目 & 単位 & 数値 & 備考 \\
\hline 一次減哀係数 $\mathrm{C} 1$ & $\mathrm{kN} \cdot \mathrm{s} / \mathrm{mm}$ & 203 & 標準値 $\times 0.90$ \\
\hline 二次減衰係数 $\mathrm{C} 2$ & $\mathrm{kN} \cdot \mathrm{s} / \mathrm{mm}$ & 2.66 & 標準值 $\times 0.95$ \\
\hline リリーフ荷重 $F r$ & $\mathrm{kN}$ & 4752 & 標準値 $\times 0.99$ \\
\hline ダンパー剛性 $K$ & $\mathrm{kN} / \mathrm{mm}$ & 900 & 標準值 $\times 1.00$ \\
\hline 取付治具等剛性 $K^{\prime}$ & $\mathrm{kN} / \mathrm{mm}$ & 1400 & 測定値 \\
\hline
\end{tabular}

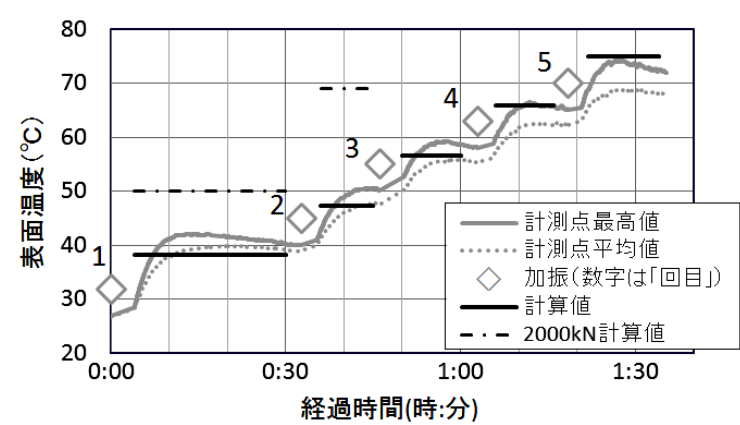

図 10 多数回繰り返し実験温度上昇計測值および計算値

表 8 加振毎の吸収エネルギー

\begin{tabular}{|c|c|c|c|}
\hline 加振 & 吸収エネルギー $(\mathrm{kJ})$ & 加振 & 吸収エネルギー $(\mathrm{kJ})$ \\
\hline 1 回目 & 15945 & 5 回目 & 12764 \\
\hline 2 回目 & 12854 & \multicolumn{2}{|c|}{-以下参考 -} \\
\hline 3 回目 & 12853 & KH 波 & 5371 \\
\hline 4 回目 & 12824 & KK1.2 波 & 4583 \\
\hline
\end{tabular}

全体を対象とした実験結果と良好に一致した。今後、この手法を用 いた製品出荷試験が可能である。

本技術は高層建物の耐震性向上および地震応答性状の改善に大い に貢献するものであり、今後の適用・展開を期待するものである。

\section{参考文献}

1) 日本免震構造協会運営委員会: 特別寄稿 2014 年度免震制振建物データ集 積結果, MENSHIN, No.89, pp.20 25, 2015.8

2) 田村, 金子, 北村, 斉藤: 2011 年東北地方太平洋沖地震における東京の高 層住宅での摇れと室内被害および対応行動に関するアンケート調査, 日本 建築学会技術報告集 第 18 巻 39 号, pp.453 458, 2012.6

3) 山本, 嶺脇, 二木, 鴨下: 高容量オイルダンパーの開発（その1）全体概要, 日本建築学会大会学術講演梗概集 B2, pp.727〜 728，2014.9

4) Caltrans Seismic Response Modification Device (SRMD) Test Facility, $<$ https://structures.ucsd.edu/node/62>, (2016-3-22 参照)

5) 中原, 露木, 山本ほか: 高容量オイルダンパーの開発（その3）出荷試験方 法の検討, 日本建築学会大会学術講演梗概集 B2, pp.731 732, 2014.9

[2015 年 12 月 1 日原稿受理 2016 年 3 月 14 日採用決定］ 